\title{
THE NEW KENOPHYTE IN POLAND - LEMNA MINUTA HUMB., BONPL. \& KUNTH
}

\author{
ANNA BANASZEK ${ }^{1}$, KRYSTYNA MUSIAE ${ }^{2}$ \\ ${ }^{1}$ Department of Plant Taxonomy and Phytogeography, \\ Institute of Botany, Jagiellonian University \\ Kopernika 27, 31-501 Kraków, Poland \\ e-mail: anna.banaszek@gmail.com \\ 2 Depatrment of Plant Cytology and Embryology, \\ Institute of Botany, Jagiellonian University \\ Grodzka 52, 31-044 Kraków, Poland
}

(Received: May 12, 2008. Accepted: June 9, 2008)

\begin{abstract}
For the first time in Poland two habitats of Lemna minuta were found in 2007. Both of them are located in the warmest south-western region of the country. L. minuta is a North-American kenophyte which has come to Poland probably from Germany. This species grows no bigger than 1-3 mm, which makes it the smallest representative of genus Lemna. The most characteristic features of $L$. minuta are the lack of purple pigmentation and the presence of only one hardly visible vein in the frond.
\end{abstract}

KEY WORDS: Lemna minuta, the least duckweed, Poland, new kenophyte, L. turionifera.

\section{INTRODUCTION}

Every year, in Poland, as in other European countries, new species of anthropophytes are discovered. The speed with which they spread is considerable and the most recent discoveries include e.g. Typha laxmanii Lepech. (Baryła et al. 2005) and Symphyotrichum ciliatum (Lindl.) Nesom. (Bróż and Podgórska 2005). Many of these newcomers are discovered after they reach a significant level of domestication and already have the status of a hemi- or holoagriophyte. In many cases, botanists are too late in recognizing a new species because it is too similar in its appearance to known taxa and therefore they escape the attention of researchers. For this reason, the earliest possible discovery of such alien newcomers is so important and includes the provision of accurate descriptions and key features (the latter might prove more difficult to obtain) as well as notifying the botanical community of their arrival. The finding of this of the concerned antropophytic duckweed in Poland is just one such case as it is the second species of anthropophytic duckweed found in Poland, after L. turionifera Landolt (Wolff and Landolt 1994) was discovered a dozen or so years ago.

\section{The family Lemnaceae in Poland}

The family Lemnaceae in Poland includes 5 species of the genus Lemna: L. trisulca L., L. gibba L., L. minor L., L. turionifera Landolt and L. minuta Humb., Bonpl. \& Kunth; one species of the genus Spirodela: S. polyrrhiza (L.) Schleid. and one species of the genus Wolffia: W. arrhiza (L.) Horkel ex Wimm.

The first three species of the genus Lemna are native to Poland. Lemna turionifera is a kenophyte which arrived from North America. It was found in 1987 by E. Landolt to the east and north of Kraków. The species arrived in Poland most likely from the east (Wolff and Landolt 1994). At present, the distribution range is greater, as the species was found upon the Vistula river by Kucharczyk (2001), and by the co-author in further 5 locations yet unpublished, situated throughout the whole of Poland.

\section{Species of Lemna new to Poland}

Lemna minuta $(=$ L. minuscula Herter) is a North-American kenophyte. It has locations in western Germany (Wolff 1991), Belgium, France, Hungary, Switzerland, Ukraine, and in Great Britain (Landolt 1986); up until 2007 it had not been found in Poland. Now two locations are known: the ponds in the Łężczok nature reserve in Racibórz and a pond in the Botanic Garden in Wrocław. As L. minuta prefers a Mediterranean climate (Landolt 1980), both locations were found in the warmest region of Poland, in shielded shallow bodies of water, where conditions ensure higher water temperatures in summer. The species has not been found to-date in the Czech Republic (Kubát 2002), although its occurrence there is probable. 

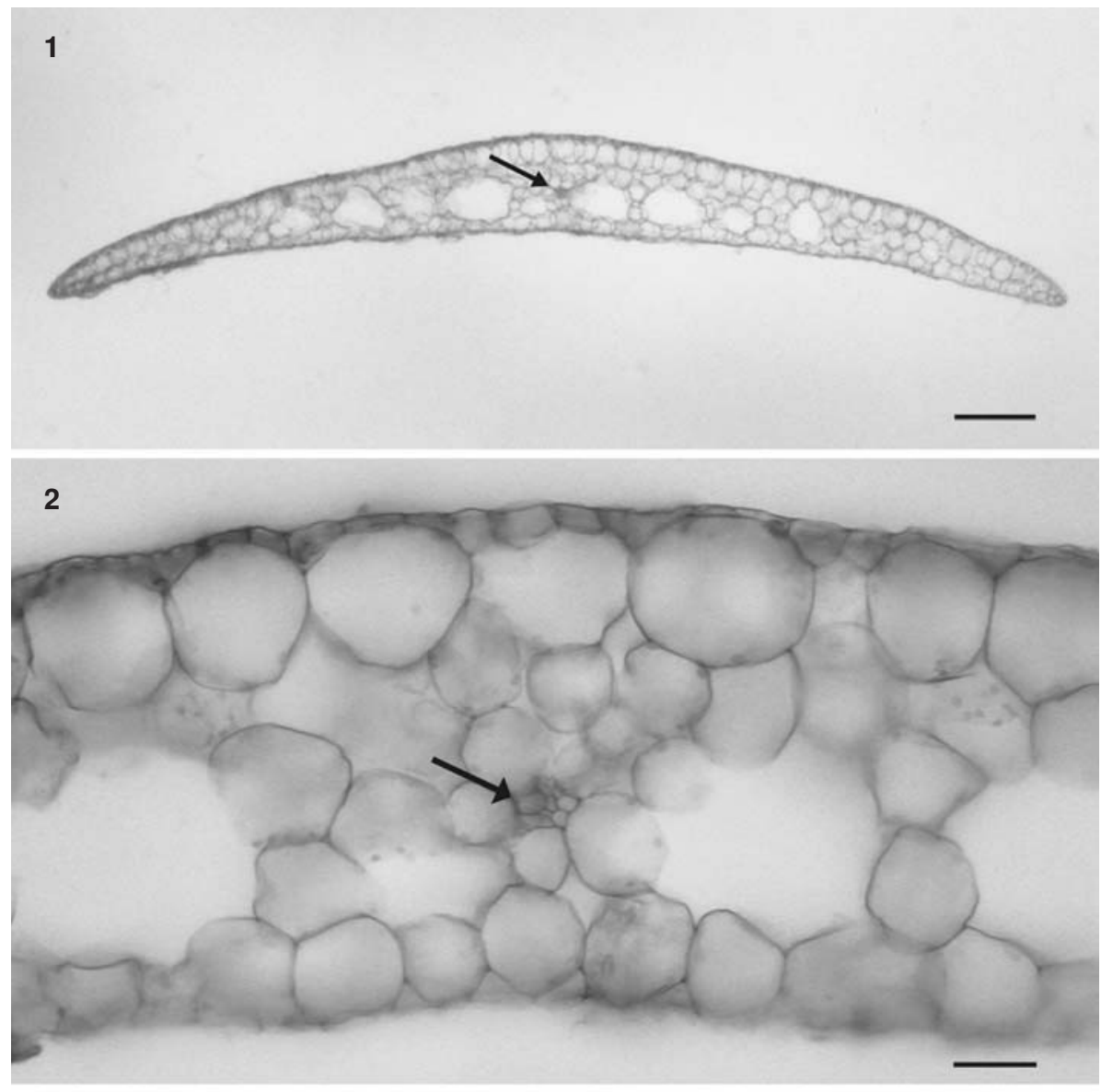

3

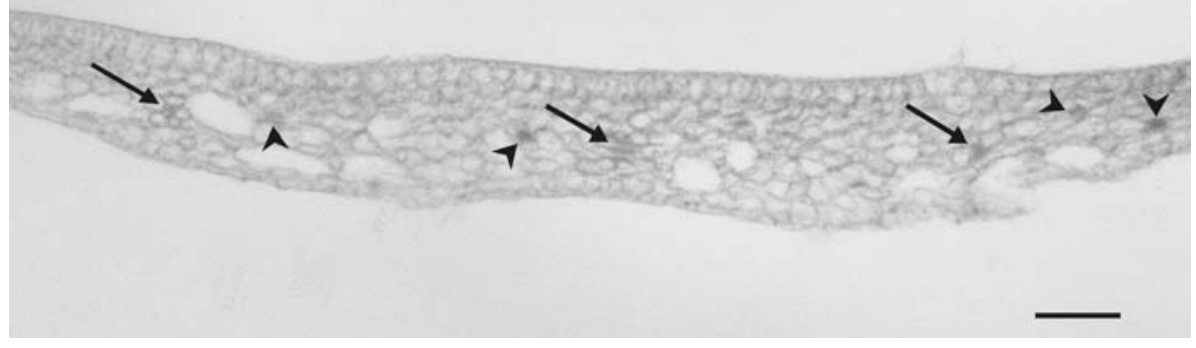

Figs 1-2. Lemna minuta. Transverse section of frond at different magnifications. Arrows indicate one vein. Fig. 1. Bar $=100 \mu \mathrm{m}$. Fig. 2. Bar $=25 \mu \mathrm{m}$.

Fig. 3. Lemna minor. Three veins are present in frond (arrows). Arrowheads show cells with crystals of calcium oxalate. Bar $=100$ $\mu \mathrm{m}$.

\section{MATERIALS AND METHODS}

Duckweed specimens were the study material. They were collected in summer 2007 in the Botanic Garden in Wrocław and in the Łężczok nature reserve in Racibórz. The fresh plant material was transferred to $70 \%$ ethyl alcohol and after $24 \mathrm{~h}$ transverse sections of fronds were made with a razor blade. The sections were stained with alum carmine and iodine green before being embedded in glycerin. The histological preparations were observed with the use of a Nikon Eclipse 400 light microscope and photographed on a Fuji 100 Sensia film.

\section{RESULTS AND DISCUSSION}

Different number of veins in the frond is one of the most important features which allows to distinguish between various species within the genus Lemna. In studied material the transverse sections of fronds showed the presence of only one vein with well developed phloem elements, whereas the failure of staining with iodine green indicates the absence of lignin within the vascular bound (Figs 1 and 2). The existence of only one vein in the frond is a characteristic feature of Lemna minuta. In L. minor three veins can be clearly seen and the frond of this species are bigger than in L. minuta (Fig. 3). The studied duckweed specimens do not show a purple pigmentation. The lack of the purple pigment is another feature of L. minuta.

\section{Taxonomic features:}

Lemna minuta Humb., Bonpl. \& Kunth

Fronds are flat, oval-oblong in outline, symmetric, the whole margin is very thin, usually pale green, shining, nearly always with a sharp ridge with a white papillae. One faint vein, reaching at most $2 / 3$ of the distance from the node to the apex. 1-3 mm long (often only $1 \mathrm{~mm}$ long when crowded and bathed in full sunlight). Often connected in clonal clusters of two and never showing a purple pigment. Fronds with one root. 


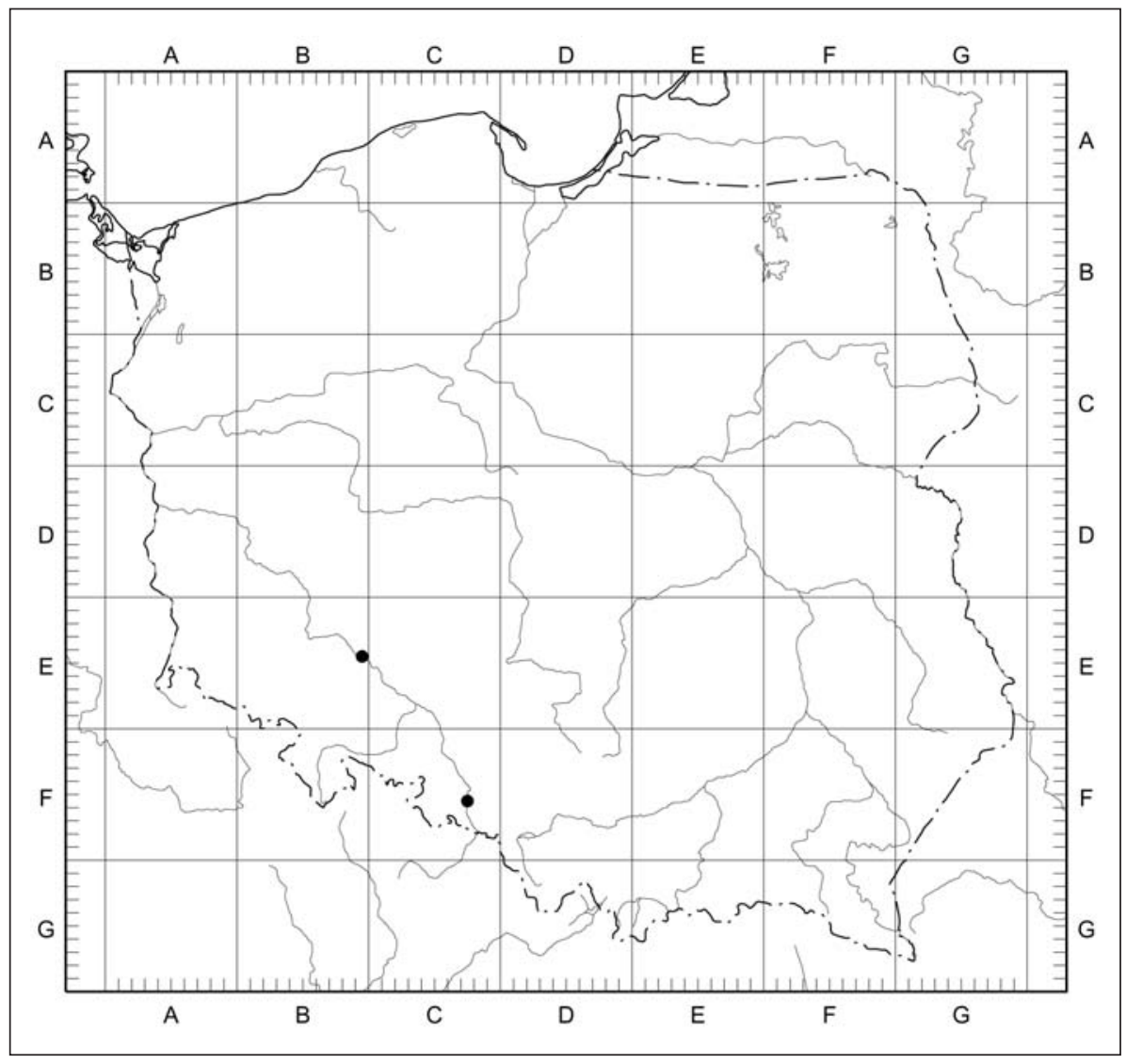

Fig. 4. The distribution map of Lemna minuta in Poland.

\section{Variability:}

When growing in sunny crowded sites, the segments of L. minuta may reach a length from 1-2 $\mathrm{mm}$, and more often than not two segments are clustered together. In sunny places, the length may reach $4 \mathrm{~mm}$, in clusters of four segments.

\section{Habitats:}

Artificial, relatively shallow bodies of water, stocked with fish, and frequented by great numbers of waterfowl. Water pure, eutrophic. Locations: sunlit or shaded. The ponds are drained for winter. Shaded sites in the warm southwestern region of Poland.

\section{Locations:}

1. The Botanic Garden, Wrocław, a large pond with a cascade. Sunny location (cartogramme unit BE49).

2. The Łężczok nature reserve in Racibórz. Shaded location (cartogramme unit CF57).

The distribution map of Lemna minuta in Poland is presented in Figure 4.

The comparison of features of Lemna minuta, L. minor and L. turionifera is presented in Table 1 .

TABLE 1. The comparison of features of Lemna minuta, L. minor and L. turionifera.

\begin{tabular}{|c|c|c|c|}
\hline Taxonomical features & Lemna minuta & Lemna minor & Lemna turionifera \\
\hline Turions & Never present & Never present & $\begin{array}{l}\text { Present in spring and autumn } \\
\text { but not always discernible }\end{array}$ \\
\hline Distribution of anthocyanis on the fronds & Never present & $\begin{array}{l}\text { Rarely present, light pink dots } \\
\text { only on upper side, } \\
\text { underside only when dried! }\end{array}$ & $\begin{array}{l}\text { Very often, mostly on underside, } \\
\text { sometimes on upper side, } \\
\text { on whole surface or in parts }\end{array}$ \\
\hline Amount of nerves & one & three & three \\
\hline Shape and colour of frond & $\begin{array}{l}\text { Elliptical, almost symmetrical, } \\
\text { light green, thin }\end{array}$ & $\begin{array}{l}\text { Oblong, light green } \\
\text { to very light green }\end{array}$ & $\begin{array}{l}\text { Oblong, mostly shining, } \\
\text { dark green (most often in spring) } \\
\text { in summer brighter }\end{array}$ \\
\hline Size of frond & $1-3 \mathrm{~mm}$, in full sunlight even $4 \mathrm{~mm}$ & $(1.2-)$ 2-4 (-6.3) $\mathrm{mm}$ & (1.4-) $2-3(-4.0) \mathrm{mm}$ \\
\hline Concentration of fronds & $\begin{array}{l}\text { Solitary or connected } \\
\text { in pairs of } 2 \text { ( } 4 \text { in full sunlight) }\end{array}$ & Connected in 4 & Connected in 3-4 \\
\hline
\end{tabular}


Key to the determination of taxa within the Lemna in Poland by Elias Landolt (Wolff and Landolt 1994) changed:

1. Fronds with one root and 1, 3 or 5 often faint nerves; fronds longer than wide, mostly smaller (Lemna) .2

2. Fronds submerged (except when fertile), very thin, somewhat transparent, stalked and mostly cohering in branched chains; margin denticulate at the apex

..Lemna trisulca $(\mathrm{L}$.

2. Fronds floating on the water surface, thicker, opaque, (nearly) not stalked, single or joined together; apex never denticulate

3. Underside of fronds with airspaces mostly longer than $0.3 \mathrm{~mm}$ mostly gibbous. Lemna gibba (L.)

3. Underside of fronds with airspaces mostly shorter than $0.3 \mathrm{~mm}$ never gibbous

4. Fronds flat, oval-oblong in outline, symmetric, whole margin is very thin; usually light green, shining, nearly always with sharp ridge with white papillae. One faint vein, reaching at most $2 / 3$ of the distance from node to apex. 1-3 mm long (often only $1 \mathrm{~mm}$ long when crowded and in full sunlight). Never with purple pigment. Fronds with one root

.Lemna minuta Humb., Bonpl. \& Kunth

4. Fronds broadly rounded at the apex, often very asymmetric; margin at best partially thin; upper side smooth, rarely somewhat shining; frond with or without a ridge, with $3(-5)$ nerves, with or without purple pigment ........5

5. Fronds nearly always with purple pigment: everywhere, in parts, on underside and/or upper side (mainly in spring), at the root insertion; other parts generally olive - green, shining, in spring can be convex, turions normally present except in mid-summer; papules in midline of the upper surface small, only the one above the node often more prominent; sometimes with longitudinal ripple; length (1-) 2-3 (-4) mm
5. Living fronds rarely with purple pigment; if present, then as dots on upper surface (mostly in the winter time); on the underside very rarely at the root base purple pigment commoner (either everywhere or in places); colour mostly light green; turions always absent; 2 papules more prominent than others, the one above the node an the one nearest the apex; often with longitudinal ridge; length (1-) 2-4 (-7) $\mathrm{mm}$ Lemna minor (L.)

\section{LITERATURE CITED}

BARYŁA J., BRÓŻ E., CZYLOK A., NIKEL A., NOBIS M., PIWOWARCZYK R., POLOCZEK A. 2005. Typha laxmanii Lepech. - the new, expansive kenophyte in Poland: dsitribution and taxonomy. Acta Soc. Bot. Pol. 74 (1): 25 -28.

BRÓŻ E., PODGÓRSKA M. 2005. Symphyotrichum ciliatum (Brachyactis ciliata) (Asteraceae) w Polsce. Fragm. Flor. Geobot. Polonica 12 (2): 291-299.

CLIVE S. 2001. New flora of the British Isles, second edition.

KUBÁT K. (ed.). 2002. Klič ke květeně Českě Republiky. 2002. Academia věd Cěskě Republiky, Praha. (in Chech)

KUCHARCZYK M. 2001. Distribution Atlas of Vascular Plants in the Middla Vistula River Valley. Maria Curie-Skłodowska Press, Lublin, pp. 1-395.

LANDOLT E. 1980. Key to determination of taxa within the family of Lemnaceae. In: Veröff. Geobot. Inst. ETH Rübel Zürich 70: 13-21.

LANDOLT E. 1986. Biosystematic investigations in the family of duckweed (Lemnaceae) (vol. 2) The family of Lemnaceae a monographic study. Volume 1. - Veröff. Geobot. Inst. ETH Stift. Rübel Zürich 71: 1-566.

WOLFF P. 1991. Die Zierliche Wasserlinse Lemna minuscula Herter: Ihre Erkennungsmerkmale und ihre Verbreitung in Deutsckands. Flor Rundbr. 14: 33-56.

WOLFF P., LANDOLT E. 1994. Spread of Lemna turionifera (Lemnaceae), the red duckweed, in Poland. Fragm. Flor. Geobot. 39 (2): 439-451. 